\title{
Accident de Tchernobyl : 30 ans déjà. Beaucoup de progrès mais des incertitudes demeurent
}

Il y a 30 ans, survenait le premier accident nucléaire civil majeur de l'ère atomique. Cet évènement, qui a conduit à la dispersion de l'ordre de $12 \times 10^{18} \mathrm{~Bq}$ de radionucléides divers et à la contamination des sols d'une partie de l'Europe, a mobilisé experts et chercheurs pendant des années et, surtout, changé la perception de la société vis-à-vis du risque radiologique. Trente ans après, de gros progrès ont été réalisés tant en ce qui concerne la sûreté des centrales, que la protection des travailleurs, des membres du public et de leur environnement. Un séminaire récemment organisé par la SFRP a du reste permis de faire un point sur cette question ${ }^{1}$. Des exercices nationaux de crise ont ainsi été progressivement mis en place en même temps que des conventions internationales permettant des échanges d'information et une assistance en cas d'accident nucléaire. Des échanges fructueux et pérennes entre les experts et les parties prenantes se sont développés sur les principaux aspects de protection et de sûreté nucléaire, permettant entre autre une meilleure prise en compte des demandes sociétales. Au niveau de la recherche, ces dernières années ont vu l'émergence de très nombreuses améliorations dont de nouveaux modèles de dispersion environnementale des radionucléides en champs proche et lointain, la prise en compte des différences anatomiques et physiologiques entre les sexes et en fonction de l'âge pour le calcul de l'incorporation des radionucléides et des doses associées, ou encore la reconnaissance d'effets jusque-là peu mentionnés dans la littérature, comme les cataractes radio-induites observées dans la population des liquidateurs.

D'autres domaines, pourtant largement explorés, n'ont cependant pas encore livré tous leurs secrets et parmi ceux-ci, les effets sanitaires des rayonnements aux faibles doses $(<100 \mathrm{mSv})$ restent encore sujets à débat. Cette incertitude sur les effets susceptibles de survenir après de faibles doses d'irradiation reste sans doute l'une des pierres d'achoppement du système de radioprotection, basé sur la notion d'acceptabilité du risque induit. Les efforts menés depuis de nombreuses décades n'ont en effet pas réussi à instaurer le consensus scientifique que cette question mériterait afin d'obtenir la confiance des personnes du public échaudées par d'autres affaires sanitaires mais également par les débats d'experts ayant suivi l'accident de Tchernobyl.

Afin de progresser, un changement de paradigme favorisant une approche globale et intégrant toutes les facettes du savoir disponible permettrait probablement de mieux tirer parti des nombreux travaux menés dans les disciplines variées et complémentaires des sciences de la vie. Une telle approche holistique pourrait favoriser le développement de méthodes et outils innovants, accélérer l'acquisition de données et, en outre, permettre l'obtention de données aux interfaces de ces disciplines largement inexplorées et où les marges de progrès restent importantes.

Ces changements d'approche pourraient ensuite être couplés à de nouvelles recherches, dédiées d'une part à l'acquisition des données nécessaires aux activités normatives en matière de contrôle des expositions et, d'autre part, au développement d'outils et de concepts permettant la mise à disposition puis la standardisation de moyens d'évaluation du risque individuel. En second lieu, cette recherche pourrait alors être étendue par le développement d'études à visée plus mécanistique, propres à comprendre puis modéliser des phénomènes pour mieux les prédire dans des conditions éloignées de celles initialement testées. De nombreux efforts restent à faire, dont on espère bien suivre les avancées dans les colonnes de notre journal favori.

${ }^{1}$ Les présentations du séminaire sont accessibles sur le site de la SFRP http://www.sfrp.asso.fr/. 


\section{Chernobyl accident : 30 years ago. A lot of progress, but uncertainties remain}

Thirty years ago, arose the first major nuclear accident of the atomic era. This event, which led to the dispersal of the order of $12 \times 10^{18} \mathrm{~Bq}$ of radionuclides and in the contamination of the grounds of a part of Europe, mobilized experts and researchers for years and, especially, changed the perception of the society towards the radiological risk. Thirty years later, large progresses were realized as regards to the safety of the power plants and to the protection of the workers, the members of the public and their environment. A seminar recently organized by the SFRP allowed reviewing these progresses ${ }^{2}$. National exercises of crisis were gradually set up at the same time as international agreements allowing exchanges of information and assistance in the event of a nuclear accident. Fruitful and long-lasting exchanges between the experts and the stakeholders were developed on the main aspects of protection and nuclear safety, allowing among others a better consideration of the societal demands. In the field of the research, these last years saw the emergence of numerous improvements among which new models of environmental dispersal of radionuclides, consideration of the anatomical and physiological differences between the sexes and according to the age for the calculation of the incorporation of radionuclides and associated doses, or even recognition of health effects barely mentioned in the literature as the radioinduced cataracts amongst the liquidators.

Other domains, nevertheless widely explored, did not deliver yet all their secrets and among these, the health effects of the radiations at low doses $(100 \mathrm{mSv})$ remain still subject to debate. This uncertainty on the effects susceptible to arise after low doses of radiation doubtless stays one of the stumbling blocks of the system of radioprotection, based on the notion of acceptability of the inferred risk. The efforts led since numerous decades did not indeed manage to establish the scientific consensus which this question would deserve, to obtain the trust of the members of the public warmed by other sanitary affairs but also by the debates of experts having followed the accident of Chernobyl.

To progress, a change of paradigm favoring a global approach and integrating all the facets of the available knowledge would probably allow taking better advantage of numerous works led in the varied and complementary disciplines of life sciences. Such a holistic approach could favor the development of methods and innovative tools, accelerate the acquisition of data and, besides, allow the obtaining of data at the interfaces of these widely unexplored disciplines and where the margins of progress remain important.

These changes of approach could be then coupled with new researches, dedicated on one hand to the acquisition of the data necessary for the normative activities regarding control of the exposures and, on the other hand, in the development of tools and concepts allowing the provision and then the standardization of methods for the evaluation of the individual risk. Secondly, this research could be then widened by the development of mechanistic studies, appropriate to understand and then model phenomena, to predict them in conditions distant from those initially tested. Numerous efforts remain to make, by which we well hope to follow the progresses in the columns of our favorite journal.

2 The presentations of the seminar are available on the SFRP website http://www.sfrp.asso.fr/. 